\title{
PERAN PEREMPUAN DALAM MENINGKATKAN \\ EKONOMI KELUARGAMELALUI PEMANFAATAN POTENSI LOKAL (PENGELOLAAN SAGU DI DESA SUNGAI BEMBAN KAB. KUBU RAYA)
}

\author{
ITA NURCHOLIFAH \\ Email: inurcholifab@yahoo.co.id \\ Dosen Fakultas Syariah dan Ekonomi Islam (FSEI)
}

\begin{abstract}
The nation's prosperity and wealth could be acknowledged from the economy sector. To improve the economy sector of one nation could not be performed half-hearted. It would need the support of all citizen, especially the smallest entity of the society - a family. The married women could also belp their husband to enhance the household finance. The effort, in addition, would be effective by processing the local natural resources. Furthermore, through the local resources utilization, the housewives especially could enhance their economy. Besides, the Sago management processed by the farmer of Sago at Sungai Bemban village is stil lack in any aspects. Because they only work on half materials called "Sagu Basab". Therefore, they need a guidance to create an excellent product of sago that could be a chance of business.
\end{abstract}

Keywords: Women Role, Household Economy, Local Goods

\section{PENDAHULUAN}

Kemajuan dan kemakmuran suatu bangsa yang sangat dicita-citakan oleh segenap rakyat tentu saja dapat di lihat pada sektor perekonomiannya. Artinya salah satu tolok ukur bagi kemajuan bangsa maupun daerah adalah bagaimana kemajuan ekonominya dapat berkembang dengan baik sehingga dengan kemajuan di sektor ekonomi tersebut dapat meningkatkan tingkat kesejahteraan bagi masyarakat atau warga penduduk bangsa. Dan sebaliknya, bila perkembangan di sektor perekonomian bangsa maupun daerah tidak berjalan dengan baik tentu harapan guna menciptakan kesejahteraan bagi segenap masyarakat akan mandek juga.

Meskipun tolok ukur kemajuan bangsa tidak hanya di ukur dari kemajuan di sektor ekonomi, tapi sektor ekonomi ini tetap memegang peranan penting guna mewujudkan kesejahteraan yang luas bagi warga bangsa maupun daerah. Sehingga pembangunan di sektor ekonomi tentu saja tidak boleh di tunda-tunda lagi, untuk itu segenap masyarakat atau rakyat Indonesia harus berupaya menggalakkan sektor pembangunan ekonomi ini semampu mungkin dan dilakukan dengan penuh semangat dan tekad untuk memajukan perekonomiannya.

Memajukan sektor perekonomian ini tentu tidak boleh dilakukan setengah-setengah, totalitas semua unsur warga bangsa atau masyarakat haruslah tergerak dengan nyata. Diberbagai tempat di Indonesia memang masih terdapat ketimpangan di dalam upaya memajukan perekonomian khususnya pada entitas terkecil masyarakat yakni keluarga. Satu hal yang mungkin menjadi salah satu sandungan dalam upaya melakukan akselerasi pembangunan perekonomian keluarga adalah adanya budaya di berbagai daerah khususnya di Indonesia ini, yang menempatkan posisi perempuan pada ranah yang kurang baik khususnya di dalam upayanya untuk turut serta kaum laki-laki dalam menggali sektor ekonomi demi memajukan perekonomian mereka. Adanya anggapan bahwa tugas perempuan khususnya yang telah berkeluarga berkisar dari "dapur - sumur - kasur", jelas membuat ruang gerak perempuan menjadi sempit untuk dapat melakukan hal-hal dalam upaya memajukan sektor perekonomian mereka. 
Budaya yang menghambat keterlibatan kaum perempuan di sektor perekonomian tentu tidak mutlak sama terjadi di semua daerah di Indonesia. Namun stigma yang berkembang di dalam kehidupan masyarakat Indonesia, memang lebih memposisikan kaum perempuan khususnya yang telah berkeluarga pada posisi kerja sebagai ibu rumah tangga, yang hanya mengurus atau bekerja mengurus keluarga khususnya anak-anak dan merapikan atau mempersihkan rumah dan perkarangannya.

Stigma tentang peran perempuan yang telah menikah atau ibu rumah tangga tersebut tidak sepenuhnya salah, memang kaum perempuan sudah dikodratkan untuk lebih memperhatikan anak-anaknya, tapi sesungguhnya di saat waktu senggang atau di saat bersamaan dalam mengurus keluarga, para perempuan yang telah berumah tangga juga dapat turut membantu suami mereka dalam peningkatan perekonomian keluarga mereka. Dan upaya tersebut tentu akan lebih efektif bila dilakukan dengan melakukan pengolahan sumberdaya lokal yang ada dilingkungan sekitar.

Desa Sungai Bemban Kecamatan Kubu Kabupaten Kubu Raya yang merupakan desa yang memiliki karunia alam yang dapat ditumbuhi tanaman pangan berupa sagu merupakan potensi yang sangat berharga khususnya untuk pemenuhan kebutuhan pangan dan hasil olahan lain dari sagu yang dapat dikelola guna menambah nilai ekonomi warga setempat sehingga bisa meningkatkan kemandirian ekonomi keluarga. Melalui pemanfaatan sumber daya lokal ini tentunya peran perempuan khususnya ibu rumah tangga akan dapat lebih efektif di dalam meningkatkan perekonomian keluarga.

Peran perempuan khususnya di desa sungai bemban ini khususnya bagi mereka yang telah berumah tangga memang sangat strategis terutama di dalam meningkatkan perekonomian keluarga sehingga kesejahteraan keluarga akan dapat terwujud sehingga harapan perkawinan guna mewujudkan keluarga yang sakinah mawaddah warahmah akan dengan sendirinya terwujud dengan baik. Tapi tentu saja peran-peran perempuan khususnya para ibu rumah tangga harus dilakukan dengan tepat dan sesuai dengan sumberdaya lokal yang ada.

\section{PERAN PEREMPUAN DALAM MENINGKATKAN EKONOMI KELUARGA}

Menurut Gross Mason, dan Mc.Eachem yang di kutip oleh David Barry, peran adalah sebagai seperangkat harapan-harapan yang dikenakan pada individu yang menempati kedudukan sosial tertentu. ${ }^{61}$ Pendapat ini jika di kaitkan dengan peran kaum perempuan khususnya ibu rumah tangga di dalam upaya meningkatkan perekonomian keluarga jelas peran mereka sangat strategis guna meningkatkan harkat dan martabat keluarga agar lebih bermartabat dan di pandang sejahtera khususnya pada lingkungan sekitar mereka.

Perempuan merupakan sosok makhluk ciptaan Allah SWT yang paling menarik untuk kaji dan ditelaah secara mendalam. Sebab perempuan merupakan sosok makhluk yang dapat berperan secara ganda di tengah-tengah masyarakat. Meskipun demikian bukan berarti perempuan harus melepaskan sifat kefeminimannya. Dan inilah wujud "seksinya" perempuan dibandingkan dengan sosok laki-laki.

Menurut Todaro dan Smith, Pekerjaan ekonomi rumah tangga kaum wanita nyaris tidak terbatas; yakni mulai dari mencari atau membeli, membersihkan serta mengolah atau memasak bahan-bahan mentah, memelihara ternak, memasak di atas kompor yang primitif, dan tentu saja semua itu dilakukan sembari mengurus, membersihkan rumah, serta memelihara anak-anaknya. ${ }^{62}$

\footnotetext{
${ }^{61}$ David Berry, Pokok-pokok Pemikiran dalam Sosiologi,(Jakarta: CV. Rajawali Press, 1984), hlm. 268.

${ }^{62}$ Michael P. Todaro dan Stephen C. Smith, Pembangunan Ekonomi,(Jakarta: Erlangga, 2006), hlm. 525.
} 
Peran ganda perempuan yang paling nyata di tengah lapangan kehidupan ini adalah kiprahnya yang bisa digerakkan khususnya di bidang ekonomi. Artinya kiprah perempuan yang menurut banyak pendapat umum hanya ditakdirkan untuk mengurus rumah tangga dalam kehidupan keluarga ternyata dapat pula secara nyata dan bersama-sama untuk bergerak dalam bidang ekonomi khususnya di dalam melakukan pemberdayaan ekonomi keluarga.

Menurut Loekman Soetrisno, perempuan bekerja baik sebagai ibu rumah tangga maupun sebagai "bread winer" di samping suami. Perempuan pada golongan ini peranan ganda seorang perempuan telah mereka terima sebagai kodrat perempuan. Karena melihat tanpa bantuan mereka sang suami tidak dapat menghidupi keluarga mereka. Kemiskinan yang melanda keluarga mereka menyebabkan perempuan-perempuan dari golongan ini tidak dapat menyerahkan kelangsungan hidup keluarga mereka kepada suami mereka. ${ }^{63}$

Peningkatan ekonomi keluarga, terlebih bagi masyarakat yang kurang mampu memang harus dilakukan secara bersama-sama antara suami dan istri sehingga dapat meningkatkan hasil kerja atau hasil usaha yang maksimal guna meningkatkan perekonomian mereka, meskipun harus juga memperhatikan atau membina anak-anak mereka dengan sebaik-baiknya.

MenurutSuprihatin Guhardja dkk, beberapa penelitian memberikan kesimpulan bahwa pengembangan sumber daya manusia dan keluarganya telah memberikan kontribusi yang cukup besar bagi pertumbuhan ekonomi. ${ }^{64}$

Pendapat di atas, semakin membuktikan bahwa penguatan ekonomi keluarga bukan hanya berdampak pada peningkatan kesejahteraan anggota keluarga itu saja. Tapi juga berdampak positif pada pertumbuhan ekonomi sebuah bangsa. Dengan kata lain semakin banyak rumah tangga atau keluarga yang mempunyai tingkat ekonomi yang baik dan maju maka semakin tinggi pula tingkat pertumbuhan ekonomi sebuah bangsa atau negara.

Perempuan khususnya para ibu-ibu rumah tangga di desa Sungai Bemban Kecamatan Kubu Kabupaten Kubu Raya sejauh yang pernah penulis amati dari proses pendampingan mereka khususnya di dalam melakukan peranan sehari-hari di dalam kehidupan berumah tangga memang terlihat aksi yang sama, yaitu bagi keluarga yang tergolong kurang mampu, para istri atau ibu rumah tangga juga terlibat secara langsung atau tidak langsung di dalam bekerja khususnya di sektor pertanian untuk mencari tambahan rezeki guna membantu suami di dalam meningkatkan ekonomi keluarga. Bahkan menurut Ester Boserup yang di kutip oleh Todaro dan Smith, dalam hampir semua kasus yang tercatat, pekerjaan di bidang pertanian sebagian besar dilakukan oleh kaum wanita. ${ }^{65}$

Peran perempuan khususnya para ibu rumah tangga di Desa Sungai Bemban yang memang telah terbiasa untuk berperan ganda, yakni melakukan pekerjaan rumah tangga dan mengurus anak-anak mereka dan juga membantu pekerjaan tani bagi suami merekadan adapula yang membuat usaha membuat jajanan tradisional guna menambah penghasilan keluarga mereka guna meningkatkan perekonomian keluarga supaya kehidupan mereka menjadi lebih sejahtera.

${ }^{63}$ Loekman Soetrisno, Kemiskinan, Perempuan, dan Pemberdayaan,(Yogyakarta: Kanisisus, 1997), hal: 97

${ }^{64}$ Suprihatin Guhardja, Hidayat Syarief, Hartoyo, Harien Puspitawati, Pengembangan Sumber Daya Keluarga,(Jakarta: PT. BPK Gunung Mulia, 1993), hlm. 2

${ }^{65}$ Michael P. Todaro dan Stephen C. Smith, Pembangunan Ekonomi,(Jakarta: Erlangga, 2006), hlm, 524. 


\section{PENINGKATKAN EKONOMI KELUARGA MELALUI PEMANFAATAN POTENSI LOKAL}

Potensi ekonomi lokal atau daerah yang dimiliki oleh suatu tempat memang sudah seharusnya dikembangkan guna meningkatkan sumberdaya perekonomian warga setempat. Menurut Suparmoko (2002: 99), potensi ekonomi daerah sebagai "kemampuan ekonomi yang ada di daerah yang mungkin dan layak dikembangkan sehingga akan terus berkembang menjadi sumber penghidupan rakyat setempat bahkan dapat mendorong perekonomian daerah secara keseluruhan untuk berkembang dengan sendirinya dan berkesinambungan."66

Segala potensi alam baik yang ada di laut maupun di daratan tentu merupakan karunia bagi umat manusia yang telah diberikan oleh Tuhan guna kebahagiaan hidup manusia itu sendiri. Dan itu merupakan harta yang tak ternilai bagi manusia yang disediakan Tuhan pada umatnya. Alangkah naifnya bila segala potensi "harta" yang telah Tuhan berikan itu tidak digunakan secara maksimal oleh umat manusia yang berada di kawasan potensi tersebut. Menurut Ma'ruf Abdullah, Agama Islam memandang harta sebagai salah satu perhiasan dunia dan juga sebagai sarana yang bisa mempermudah hidup manusia. ${ }^{67}$

Pemanfaatan potensi alam yang ada disekitar lingkungan hidup manusia tentu harus dimanfaatkan sebaik-baiknya, terutama potensi tumbuhan pangan yang sangat bermanfaat bagi kehidupan manusia secara luas. Menurut Zuhal, bahwa "ancaman ketahanan pangan, kesehatan, dan energy bukan isapan jempol." ${ }^{\prime 68}$ Sehingga upaya pemanfaatan lahan untuk kebutuhan pangan mutlak dilakukan. Pemanfaatan tersebut tentunya bukan hanya di olah untuk pemenuhan kebutuhan pribadi sebagai upaya untuk menopang kehidupan dari hari ke hari saja, tapi sebaiknya juga dapat dimanfaatkan untuk kebutuhan luas bagi masyarakat yang lain sehingga dapat menjadi nilai tambah untuk menopang kemandirian ekonomi warga.

Ketahanan pangan di suatu Negara maupun daerah adalah merupakan masalah/isu yang sangat penting. Sehingga pemerintah mengeluarkan kebijakan berupa Peraturan Pemerintah nomor 68 Tahun 2002 tentang ketahanan pangan. "bahwa ketahanan pangan merupakan hal yang sangat penting dalam rangka pembangunan nasional untuk membentuk manusia Indonesia yang berkualitas, mandiri, dan sejahtera melalui perwujudan ketersediaan pangan yang cukup, aman, bermutu, bergizi dan beragam serta tersebar merata di seluruh wilayah Indonesia dan terjangkau oleh daya beli masyarakat;

Sedangkan Undang-Undang Republik Indonesia Nomor 18 Tahun 2012 tentang pangan, pada pasal 1 yang dimaksud dengan pangan adalah segala sesuatu yang berasal dari sumber hayati produk pertanian, perkebunan, kehutanan, perikanan, peternakan, perairan, danair,baik yang diolah maupun tidak diolah yang diperuntukkan sebagai makanan atau minuman bagi konsumsi manusia, termasuk bahan tambahan Pangan, bahan baku Pangan, dan bahan lainnya yang digunakan dalam proses penyiapan, pengolahan, dan/atau pembuatan makananatau minuman.

Salah satu potensi tumbuhan pangan yang tidak semua daerah punya potensi pengembangannya adalah tumbuhan sagu. Tumbuhan sagu hanya dapat tumbuh dan berkembang di daerah-daerah tertentu di negeri ini. Dan salah satu tempat yang cukup potensial pertumbuhan tanaman sagu tersebut adalahdi Desa SungaiBemban Kecamatan Kubu Kabupaten Kubu Raya Provinsi Kalimantan Barat.

\footnotetext{
${ }^{66}$ Suparmoko, M, Ekonomi Publik untuk Keuangan dan Pembangunan Daerah, (Yogyakarta: Andi Offset, 2002),hlm. 99.

${ }^{67}$ M. Ma'ruf Abdullah, Wirausaha Berbasis Syariah, (Yogyakarta: Aswaja Pressindo, 2013), hlm. 8.

${ }^{68}$ Zuhal, Gelombang Ekonomi Inovasi, (Jakarta:PT. Gramedia Pustaka Utama, 2013), hlm. 127.
} 
Desa Bemban secara umum terbagi menjadi 2 wilayah. Yaitu wilayah Bemban Timurdan wilayah Bemban Barat, dengantotal luas wilayah 16 kilo meter persegi dan terbagi menjadi beberapa dusun dan RT yaitu : Dusun Karya Melati RT 1- 4, Dusun Karya Ingin Maju RT 5-7, Dusun Bersama RT 8-11, Dusun Karya Baru RT 12-14. Dan mayoritas penduduk Desa Bemban adalah penganut agama Islam.

Adapun waktu yang ditempuh untuk menuju Desa Sungai Bemban dari Pontianak memakan waktu dua sampai tiga jam perjalanan, dengan kondisi jalan tanah liat dan masih banyak yang berlubang. Perjalanan dua sampai tiga jam ini ditempuh dengan dua kali jalan darat dan satu kali penyebrangan sungai. Kondisi penyebrangan yang masih menggunakan motor air atau kelotok yang kecil ini, hanya mampu mengangkut kendaraan roda dua. Kondisi jalan darat yang masih sepi, dengan rute jalan darat melewati permukiman warga, kebun sawit, hutan belantara, dan pertanian padi.Kondisi jalan yang masih belum bisa dilewati mobil ini, yang mengharuskan pengguna jalan atau pengunjungmenggunakan kendaraan beroda dua (sepeda motor) untuk menuju Desa Sungai Bemban.

Kondisi infrastruktur yang masih belum memadai ini tidak membuat semangat warga Desa sungai Bemban menjadi surut untuk tetap bekerja dan beraktifitas meskipun halangan atau kendala transportasi yang masih belum memadai untuk sampai dengan cepat dan lancar ke ibu kota kecamatan maupun ibu kota kabupaten.

Mayoritas warga Bemban bekerja di sektor pertanian, baik mengelola sawah maupun mengolah sagu yang merupakan tumbuhan pangan yang banyak tumbuh di desa tersebut. Berdasarkan hasil penelitian yang dilakukan, terdapat delapan pabrik sagu di desa sungai bemban. Delapan pabrik sagu tersebut adalah milik warga desa sungai bemban, yaitu :

Tabel. 1

Data Pabrik Tepung Sagu Basah di Desa Sungai Bemban

\begin{tabular}{|c|l|l|}
\hline No. & \multicolumn{1}{|c|}{ Nama Pemilik } & \multicolumn{1}{|c|}{ Alamat } \\
\hline 1 & Japaren & Jl. Parit Kancil Desa Sungai Bemban \\
\hline 2. & Lose & Jl. Parit Kancil Desa Sungai Bemban \\
\hline 3. & Hatta & Jl. Parit Kancil Desa Sungai Bemban \\
\hline 4. & Usop & Jl. Parit Kancil Desa Sungai Bemban \\
\hline 5. & Aban & Jl. Parit Kancil Desa Sungai Bemban \\
\hline 6. & Jamal & Jl. Parit Kancil Desa Sungai Bemban \\
\hline 7. & Awi & Jl. Parit Kancil Desa Sungai Bemban \\
\hline 8. & Akiang & Jl. Sungai Pungkur Desa Sungai Bemban \\
\hline
\end{tabular}

Sumber : Penelitian Maisuri 2015

Pengolahan sagu yang dilakukan oleh warga masyarakat Bemban hingga saat ini masih dirasakan kurang maksimal, mengingat pengolahan yang dilakukan hanya sampai pada bahan setengah jadi atau yang lebih dikenal dengan sagu basah. Meskipun para petani sudah mendapatkan keuntungan dari pengolahan sagu tersebut tapi belum cukup maksimal dalam memberikan nilai tambah bagi keluarga khususnya untuk menopang kemandirian ekonomi keluarga setempat. Untuk itu perlu upaya yang lebih maksimal dalam melakukan pengolahan sagu tersebut sehingga dapat menghasilkan kemandirian ekonomi warga desa Bemban. 
Menurut Buchari Alma (2011: 19), khususnya masyarakat pedesaan, yang tingkat pendidikan formalnya rata-rata hanya tamatan Sekolah Dasar, maka pendidikan kewirausahaan harus secara penuh diberikan untuk tiga unsur, antara lain :

1. Sikap mental wiraswasta

2. Kewaspadaan mental wirawsasta

3. Keahlian dan keterampilan wiraswasta. $9^{69}$

Berdasarkan tiga unsur tersebut hal yang patut dibenahi adalah upaya peningkatan pengolahan sagu sehingga lebih dapat meningkatkan hasil ekonomis yang mampu meningkatkan kemandirian ekonomi keluarga. Oleh karena itu fokus kegiatan pengabdian masyarakat ini yaitu pemanfaatansagu sebagai potensi ekonomi lokal untuk menguatkan kemandirian ekonomi keluarga muslim dalam bentuk pelatihan dan praktek pemanfaatan sagu sehingga sagu yang masih basah dapat dikelola menjadi produk makanan. Diharapkan juga dari pengabdian yang diperuntukkan untuk masyarakat di desa Sungai Bemban membawa perubahan dalam rangka mengelola sagu sebagai potensi ekonomi lokal menjadi suatu produk unggulan desa. Selain tanaman sagu dan tanaman lainnya, desa Sungai Bemban memiliki potensi alam berupa tempattempat wisata, seperti : batu masjid, batu sempit, dan gunung wangkang. Jika dihubungkan dengan pengolahan sagu sebagai produk unggulan dengan tempat-tempat wisata tersebut, maka produk dari bahan dasar sagu bisa dikenalkan maupun dijadikan sebagai oleh-oleh atau buah tangan para pengunjung wisata di desa Sungai Bemban.

Sebagian besar warga Desa Bemban bekerja di sektor pertanian, baik mengelola sawah atau padi maupun mengolah sagu. Dengan lahan yang subur sehingga tanaman sagu yang merupakan tumbuhan pangan yang banyak tumbuh di desa tersebut merupakan tumbuhan yang memiliki potensi yang tinggi.

Pengelolaan sagu yang dilakukan oleh para petani sagu desa Sungai Bemban hingga saat ini masih dirasakan belum maksimal, mengingat dalam hal pengolahan yang dilakukan mereka hanya sampai pada tahap pembuatan bahan setengah jadi atau yang lebih dikenal dengan istilah "sagu basah". Sagu basah tersebut lalu di jual ke pabrik sagu. untuk harga tepung sagu basah dijual dengan harga Rp. 1.800,-/kg nya.

Masyarakat desa sungai Bemban mengolah sagu untuk dijadikan berbagai jenis makanan, seperti : mie sagu, lempeng sagu, cendol, roti dan kerupuk. Namun makanan tersebut hanya sebatas untuk konsumsi keluarga saja, belum menjadi suatu produk unggulan. Dikarenakan belum maksimalnya pengolahan sagu menjadi produk unggulan desa, oleh karena itu perlu adanya pendampingan dalam pengolahan tanaman sagu untuk menjadi produk unggulan di desa sungai Bemban dan dapat dijadikan peluang dalam berbisnis/berusaha oleh ibu-ibu rumah tangga dan remaja putri desa Bemban.

Strategi yang digunakan dalam kegiatan ini adalah dengan : (1)Melakukan observasi dan komunikasi dengan mendatangi aparat desa untukmenyampaikan maksud dan tujuan dari pengabdian kepada masyarakat di desa Sungai Bemban. (2) Dari hasil komunikasi diperoleh bahwa masyarakat desa sungai bemban kesehariannya bekerja di kebun, sehingga untuk melakukan kegiatan pelatihan menyesuaikan dengan waktu peserta. Selain itu, Melakukan Teknical Meeting (FGD) yang dihadiri oleh tim pengabdian, kepala desa, para ibu PKK dan remaja putri. (3)Kegiatan pelatihan, kegiatan pelatihan ini diikuti oleh 40 orang peserta. (4) praktek pengolahan sagu oleh peserta, (5) Pendampingan dan (6) Monitoring.

\footnotetext{
${ }^{69}$ Buchari Alma, Kewirausahaan, (Bandung: Alfabeta, 2011), hlm. 9.
} 
Sepanjang proses persiapan, pelaksanaan kegiatan pelatihan hingga monitoring yang dilakukan tim pengabdian kepada masyarakat kepada 40 peserta yang terdiri dari para ibu rumah tangga dan remaja putri di desa Sungai Bemban, kegiatan pengabdian pada masyarakat ini memberikan hasil sebagai berikut, Pertama, meningkatnya semangat dan kepercayaan diri para ibu rumah tangga dan remaja putri di desa sungai bemban dalam mengenal kemampuan / potensi dalam dirinya.Kedua, semangat dan keinginan para ibu rumah tangga dan remaja putri dalam mengolah sagu yang akan dijadikan sebagai produk unggulan desa, yaitu desa sungai Bemban. Ketiga, adanya keinginan para ibu untuk membuka usaha (berwirausaha). Sehingga dapat meningkatakan /menambah pendapatan dalam keluarga. Keempat, semangat dan keinginan para ibu dan remaja putri untuk mengikuti pelatihan-pelatihan yang diadakan oleh lembaga-lembaga pelatihan di luar desa Bemban.

Pemanfaatan potensi lokal berupa tanaman tumbuhan pangan sagu yang memang tidak dapat tumbuh di semua tempat, membuat kaum perempuan khususnya ibu-ibu rumah tangga di desa Sungai Bemban ini menemukan harapan besar dan tentunya juga pendapatan yang lebih khususnya di dalam meningkatkan perekonomian keluarga mereka yang harus mereka topang bersama suami guna mensejahterakan kehidupan keluarga.

\section{PENUTUP}

Ada beberapa hal dari paparan di atas yang dapat dijadikan simpulan, antara lain :

1. Perempuan khususnya ibu rumah tangga mempunyai kemampuan untuk bekerja keras selain berperan sebagai peran besar dalam menjaga anak-anaknya, ibu rumah tangga juga dapat berperan sebagai pembantu suami di dalam meningkatkan ekonomi keluarga.

2. Dalam upaya peningkatan ekonomi keluarga, kaum perempuan terutama ibu rumah tangga sebaiknya memanfaatan potensi lokal yang dekat dengan lingkungan alam kehidupan mereka.

3. Guna melakukan efektifitas peran dalam peningkatan ekonomi keluarga dengan memanfaatkan potensi lokal rumah tangga sebaiknya mendapatkan bimbingan dan pelatihan seperti yang pernah dilakukan di desa Sungai Bemban Kecamatan Kubu.

4. Terdapat peningkatan semangat dan kinerja kaum perempuan khususnya ibu rumah tangga di desa Sungai Bemban dalam melakukan pengelolaan potensi lokal berupa sagu guna meningkatkan pereonomian keluarga mereka.

Adapun saran yang dapat penulis kemukakan dari paparan di atas, antara lain :

1. Perlu dilakukan sosialisasi dan pembinaan akan peran strategis kaum perempuan terutama ibu rumah tangga di dalam membantu suami dalam meningkatkan perekonomian keluarga.

2. Seluruh stakeholder terutama pemerintah baik daerah maupun pusat untuk memperbanyak kegiatan pembinaan dan pengembangan kaum perempuankhususnya ibu rumah tangga di bidang perekonomian seperti yang dilakukan di desa Sungai Bemban Kecamatan Kubu Kabupaten Kubu Raya Provinsi Kalimantan Barat agar dapat terciptanya keluarga-keluarga yang tangguh yang mmpunyai kemampuan ekonomi yang baik sehingga dapat memperkuat laju perkembangan perekonomian bangsa. 


\section{DAFTAR PUSTAKA}

Buchari Alma. 2011. Kewirausahaan.Bandung: Alfabeta.

David Berry. 1984.Pokok-pokok Pemikiran Dalam Sosiolog. Jakarta, CV. Rajawali Press.

Loekman Soetrisno. 1997. Kemiskinan, Perempuan, dan Pemberdayaan, Yogyakarta: Kanisius.

Michael P. Todaro dan Stephen C. Smith.2006.Pembangunan Ekonomi. Jakarta: Erlangga.

M. Ma'ruf Abdullah. 2013. Wirausaha Berbasis Syariah, Aswaja Pressindo, Yogyakarta.

Suparmoko, M,2002.Ekonomi Publik untuk Keuangan dan Pembangunan Daerah. Yogyakarta: Andi Offset.

Suprihatin Guhardja, Hidayat Syarief, Hartoyo, Harien Puspitawati. 1993.Pengembangan Sumber DayaKeluarga. Jakarta:PT. BPK Gunung Mulia.

Zuhal.2013. Gelombang Ekonomi Inovasi. Jakarta: PT. Gramedia Pustaka Utama. 